\title{
Intensity and frequency of moral distress in Brazilian nurses
}

\author{
Intensidade e frequência de distresse moral em enfermeiros brasileiros \\ Intensidad y frecuencia de distrés moral en enfermeros brasileños
}

How to cite this article:

Ramos FRS, Barth PO, Brehmer LCF, Dalmolin GL, Vargas MA, Schneider DG. Intensity and frequency of moral distress in Brazilian nurses. Rev Esc Enferm USP. 2020;54:e03578. doi: https://doi.org/10.1590/S1980-220X2018020703578

\section{Flavia Regina Souza Ramos ${ }^{1}$ \\ Priscila Orlandi Barth ${ }^{1}$ \\ D Laura Cavalcanti de Farias Brehmer $^{2}$ \\ Graziele de Lima Dalmolin ${ }^{3}$ \\ Mara Ambrosina Vargas ${ }^{1}$ \\ Dulcinéia Ghizoni Schneider ${ }^{1}$}

${ }^{1}$ Universidade Federal de Santa Catarina, Programa de Pós-Graduação em Enfermagem, Florianópolis, SC, Brazil.

${ }^{2}$ Universidade Federal de Santa Catarina,

Departamento de Enfermagem, Florianópolis, SC, Brazil.

${ }^{3}$ Universidade Federal de Santa Maria, Santa Maria, RS, Brazil.

\begin{abstract}
Objective: To evaluate the frequency and intensity of moral distress in Brazilian nurses. Method: Cross-sectional study performed with nurses from 27 Brazilian states through application of the Brazilian Moral Distress Scale in Nurses (Portuguese acronym: EDME-Br) and descriptive statistical analysis. Results: Participation of 1,226 Brazilian nurses in the study. The intensity and frequency of overall moral distress were rated as moderate level, with averages of $3.08( \pm 1.45)$ and $2.94( \pm 1.37)$, respectively. Specifically, the highest intensity and frequency was related to the factors Acknowledgement, power and professional identity and Work teams, while the lowest was related to the factor Defense of values and rights. Conclusion: Moral distress occurs in precarious work environments, with little expressiveness of the nurses' role. One highlights the importance of the problem in terms of its amplitude and multicausality, reaching professionals acting in different work contexts.
\end{abstract}

\section{DESCRIPTORS}

Ethics, Nursing; Working Conditions; Patient Care Team; Morale; Burnout, Professional. 


\section{INTRODUCTION}

Labor aspects, such as working conditions, overload, skills and competences for the performance, relationship with the team and institutional norms, permeate the work process of nurses and are associated with physical, emotional and moral distress $(\mathrm{MD})^{(1-6)}$. The occurrence of $\mathrm{MD}$ is associated with concrete conditions and the subjective work experience, especially the daily challenges, such as clinical decisions and care management. Moral distress is characterized as pain and emotional imbalance experienced when nurses recognize the correct decision or course of an action, but due to institutional constraints or barriers of various orders, cannot develop the action defined as morally correct ${ }^{(6)}$.

Moral distress has been debated in various scenarios in the world context as a unique ethical and moral procedural experience. It does not end in the episode, but produces transformation in the subject, has residual and immediate reactive effects, repercussions on the individual, and on the care provided $^{(1-2,7-12)}$.

In Brazil, a specific theoretical framework was developed. In the approach to MD, the particularities of this scenario were considered as a process linked to moral experience in articulation with elements and concepts such as moral sensitivity, moral deliberation, moral problem and the development of ethical and moral competences ${ }^{(13)}$. In view of ruptures and conceptual continuities, MD was analyzed from the reflection on spaces of power and resistance and patients advocacy, and also related to the ethical, political and advocacy inexpressiveness of professionals ${ }^{(14)}$. This theoretical framework formed the basis of the present study and of the development of the Brazilian Moral Distress Scale in Nurses (Portuguese acronym: EDME-Br) ${ }^{(15)}$.

The relevance of studying the object in the Brazilian scenario was justified by the own complex characteristics of work in health services, especially by its organization governed by the public national Health System (Brazilian SUS) that emphasizes the transformation of the care model, assumes the principle of integrality, and values the interdependence in the work of multiple professionals. By focusing on a national scenario and unrestricted to one type of service or specialty, the forms of work organization as well as the difficulties and particularities of health services represent very different conditions and challenges from other more widely studied scenarios. Professional experiences are produced in their contexts of action, and the evaluation of Brazilian nurses' moral distress should capture the diversity of their scenarios, either in geographical or labor terms. In addition to international studies addressing almost exclusively the MD of nurses working in hospitals and specialized services $^{(16-18)}$, the Brazilian Health System constitutes a unique and differentiated policy, where the profession acquires distinct historical and institutional nuances, which would already justify the use of an instrument specially built for the Brazilian reality.

Thus, the need to evaluate the MD of Brazilian nurses in the scope and extent of the national context, in the diversity of health services and their forms of work organization that may or may not be favorable to the health and ethical performance of these workers. The aim of the present study was to evaluate the frequency and intensity of moral distress in Brazilian nurses.

\section{METHOD}

\section{Study DESIGN}

This is a cross-sectional study conducted with Brazilian nurses from all regions of the country and from different types of care services.

\section{Population}

The study population comprised 451,666 nurses distributed in the 27 units of the federation (26 states and the Federal District), as registered by the Federal Council of Nursing (Portuguese acronym: COFEN).

For the selection of participants, the inclusion criteria were to be graduated in nursing and have current or previous experience in the field of care.

Non-probabilistic sampling was used. For statistical purposes, a minimum sample was calculated based on the population presented through the use of a finite sampling formula, $95 \%$ confidence level and 0.5 sample error, thus estimating a minimum of 380 participants ${ }^{(19)}$. A final sample of 1,226 respondent nurses was obtained.

\section{Data collection}

Data were collected electronically via Google.docs from November 2015 to May 2016. Initially, contacts were made for convenience with nurses, especially managers and university teachers from different regions of the country. During searches for public and private health service institutions, it was requested that the invitation email and the link to the electronic instrument were made available in the institutions. Given the low reach of this collection, it was reinforced through social network by inviting those who identified with the "nurse" profession. When accessing the instrument, the respondent was informed about the survey and asked to continue only if they met the inclusion criteria. Afterwards, the respondent was directed to read the Informed Consent form. Only after agreement, they had access to the instrument.

The instrument applied was the EDME-Br, developed and validated in the Brazilian context ${ }^{(15)}$. This is a six-point Likert scale that evaluates the frequency and intensity of moral distress, where $0=$ never/none, $6=$ very frequent/very intense, and 3 is the mean value. The scale initially contemplates a part of sociodemographic and work characterization, consisting of the variables age, sex, state, time since graduation, further education, number of employment bonds, type and nature of bond, place of work, time of work and weekly workload; and the scale with 49 items distributed in six factors.

The six MD assessment factors measured by the EDME-Br are "Acknowledgement, power and professional identity" (eleven items), "Safe and qualified care" (eleven items), "Defense of values and rights" (eight items), "Work conditions" (six items), "Ethical infractions" (six items) and "Work teams" (seven items) $)^{(15)}$. 


\section{DATA ANALYSIS AND PROCESSING}

For data analysis, the program PASW Statistic ${ }^{\circledR}$ (Predictive Analytics Software, SPSS Inc., Chicago, USA) version 22.0 for Windows was used. The analysis of the intensity and frequency of moral distress was operationalized through each of the six factors of the scale and by analysis of the overall $\mathrm{MD}$, considering the six factors together.

Descriptive statistics with relative and absolute frequency distribution was used for categorical variables. For quantitative variables, the presentation of medians and interquartile range was used by finding asymmetric distribution of data. Data normality was tested by the Kolmogorov-Smirnov test. In the descriptive analysis of factors, the Pearson's coefficient of variation was used to verify the representativeness of the means, adopting values below $50 \%$ as representative.

\section{ETHICAL ASPECTS}

This is a multicenter study. It was approved by the Research Ethics Committee of the universities involved, under the following opinion numbers: $602.598-0$ of 02/10/2014 (Universidade Federal de Santa Catarina);
602.603-0 of 01/31/2014 (Universidade Federal de Minas Gerais) and 511.634 of 01/17/2014 (Universidade Federal do Rio Grande). The guidelines issued by Resolution 466/2012 of the National Health Council were followed and all participants signed the Informed Consent form.

\section{RESULTS}

The study included 1,226 Brazilian nurses, mostly female $(n=1148-93.6 \%)$, aged between 30 and 39 years $(n=512-$ $41.8 \%$ ), with up to 10 years of training ( $n=759-62.3 \%)$, a single employment bond ( $n=863-70.8 \%$ ), up to five years of work in the same institution ( $\mathrm{n}=625-51 \%)$, weekly workload of 31 to 40 hours ( $n=619-50.5 \%$ ), with Specialization/ Residency $(n=800-65.3 \%)$ and working in the public sector ( $n=824-67.2 \%)$. According to professional records of the Federal Council of Nursing, there was a regional representation of participants and a similar distribution of active professionals in the country, except for the larger number of participants from the South region and the lower number from the Northeast region of the country (Table 1).

Table 1 - Distribution of participants by regions of the country, compared to record data of active professionals by region - Brazil, 2018.

\begin{tabular}{|c|c|c|c|c|c|c|c|}
\hline Country regions & North & Northeast & Midwest & South & Southeast & No answer & Total \\
\hline Distribution of sample participants $(n=1,226)$ & $6.6 \%$ & $14.1 \%$ & $8.4 \%$ & $22.2 \%$ & $41.9 \%$ & 6.8 & 100 \\
\hline Distribution of registered nurses $(n=451,666)$ & $6.6 \%$ & $24.4 \%$ & $7.9 \%$ & $13.0 \%$ & $48.1 \%$ & - & 100 \\
\hline
\end{tabular}

* COFEN (Federal Council of Nursing), 2016.

The descriptive results of the frequency and intensity of the items of each factor of nurses' moral distress are shown in Table 2. All items of the factors "Acknowledgement, power and professional identity" and "Work conditions" had the same median value. In the factor "Safe and qualified care", the item 32 - Recognizing routines and practices that are inappropriate to the relatives/companions'safety - presented a lower median compared to others of the same factor, both in intensity and frequency. In the factor "Defense of values and rights", the item 44 stood out - Feeling impotent to defend the patient's autonomy - with the largest median of intensity and frequency. In the factor "Ethical infractions", the item 18 - Experiencing omission by the physician - presented a wider interquartile range, assuming higher values. Finally, in the factor "Work teams", the item 3 stood out Experiencing conditions of work overload -, which presented the largest intensity and frequency medians of the factor and the instrument.

Table 3 presents the descriptive statistics of the EDME-Br factors, demonstrating that the largest medians were present in the factor Acknowledgement, power and professional identity. This factor is related to issues of autonomy and identity of nurses, attributions and deviation of attributions performed by these professionals that arouse feelings and experiences of devaluation and disrespect generated by attitudes of other professionals, discrimination and pressure by superiors and users. In contrast, the lowest medians were those of the factor Defense of values and rights, in which only one item (44 - Feeling impotent to defend the patient's autonomy) had a value close to the overall mean of MD. Among the remaining seven items of this factor, one of them (39-Experiencing care conducts that ignore the patients' beliefs and culture) had the lowest value in the scale. In summary, this factor incorporates issues related to abuse or disrespect for the rights of autonomy, privacy, confidentiality, information.

When analyzing the predictors of $\mathrm{MD}$ with higher values of frequency and intensity, factors 1 - Working with an insufficient number of professionals to attend to the demand and 3 - Experiencing conditions of work overload expressed significant intensity and frequency of $\mathrm{MD}$, both with the largest medians of the scale. These two items are included in the Work Teams factor, which in turn, presented the largest medians of intensity and frequency of MD compared to the other factors. In this factor, the numerical shortage of professionals and work overload stood out. Although these are linked to working conditions, in this study, they constituted their own construct, bringing together quantitative and qualitative dimensions of the workforce.

Finally, by analyzing all factors, as well as the overall $\mathrm{MD}$, intensity and frequency values of MD were moderate and close to the midpoint of the scale (median values around 3.0). 
Table 2 - Descriptive analysis of EDME-Br items according to its six factors - Brazil, 2018.

\begin{tabular}{|c|c|c|c|c|}
\hline \multirow{2}{*}{ Variables } & \multicolumn{2}{|r|}{ Intensity } & \multicolumn{2}{|r|}{ Frequency } \\
\hline & $\mathbf{N}$ & Md (IIq) & $\mathbf{n}$ & $\operatorname{Md}(\mathrm{Ilq})$ \\
\hline \multicolumn{5}{|l|}{ Factor 1 - Acknowledgement, power and professional identity } \\
\hline 14 Feeling discriminated by/in relation to other professionals & 1163 & $3.00(1.00-5.00)$ & 1202 & $3.00(1.00-4.00)$ \\
\hline 15 Feeling unappreciated in relation to other professionals & 1161 & $3.00(2.00-6.00)$ & 1203 & $3.00(2.00-6.00)$ \\
\hline 16 Executing actions that are not inherent in one's function & 1158 & $3.00(2.00-6.00)$ & 1199 & $3.00(2.00-5.00)$ \\
\hline 34 Having one's autonomy limited in the decision about the nursing team's specific conducts & 1148 & $3.00(2.00-5.00)$ & 1191 & $3.00(2.00-5.00)$ \\
\hline 35 Experiencing conflicting relations concerning the health team members' attributions & 1160 & $3.00(2.00-5.00)$ & 1194 & $3.00(2.00-5.00)$ \\
\hline 36 Working under pressure due to the insufficient time to reach goals or accomplish tasks & 1161 & $3.00(2.00-6.00)$ & 1196 & $3.00(2.00-6.00)$ \\
\hline 37 Recognizing situations insulting to the professional & 1159 & $3.00(2.00-6.00)$ & 1193 & $3.00(2.00-5.00)$ \\
\hline 38 Recognizing situations of disrespect for the professional's privacy & 1148 & $3.00(2.00-5.00)$ & 1196 & $3.00(2.00-5.00)$ \\
\hline 40 Feeling disrespected by hierarchical superiors & 1154 & $3.00(2.00-6.00)$ & 1196 & $3.00(1.00-5.00)$ \\
\hline 41 Recognizing ethically incorrect attitudes of managers or hierarchical superiors & 1153 & $3.00(2.00-6.00)$ & 1193 & $3.00(2.00-5.00)$ \\
\hline 43 Feeling pressured by the user due to situation one cannot intervene in & 1153 & $3.00(2.00-6.00)$ & 1194 & $3.00(2.00-5.00)$ \\
\hline
\end{tabular}

Factor 2 - Safe and qualified care

23 Recognizing the insufficient service access for the user

24 Recognizing that the users' welcoming is inadequate

25 Recognizing that the patient/user's demand for continuing care are not attended

26 Recognizing the lack of problem-solving ability of health actions due to social problems

27 Recognizing the lack of problem-solving ability due to the low quality of attendance

28 Recognizing that educative actions involving the user are insufficient

29 Experiencing disrespect for the humanized care practices recommended in public policies

30 Recognizing routines and practices that are inappropriate to professional safety

31 Recognizing routines and practices that are inappropriate to patient safety

$11523.00(2.00-6.00) \quad 1204 \quad 3.00(2.00-5.00)$

$11623.00(2.00-5.00) \quad 1205 \quad 3.00(2.00-5.00)$

$11533.00(2.00-6.00) \quad 11993.00(2.00-5.00)$

$11553.00(2.00-6.00) \quad 1194 \quad 3.00(2.00-5.00)$

$1153 \quad 3.00(2.00-5.00) \quad 1196 \quad 3.00(1.00-4.75)$

$11553.00(2.00-5.00) \quad 11893.00(2.00-5.00)$

$11573.00(2.00-5.00) \quad 1196 \quad 3.00(2.00-5.00)$

$11603.00(2.00-5.00) \quad 1195 \quad 3.00(2.00-5.00)$

$11523.00(2.00-5.00) \quad 1195 \quad 3.00(1.00-5.00)$

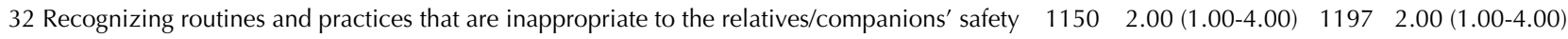

33 Recognizing care impairments due to inappropriate integration among the services/sectors

$1152 \quad 3.00(2.00-5.00) \quad 1194 \quad 3.00(2.00-5.00)$

Factor 3 - Defense of values and rights

39 Experiencing care conducts that ignore the patients' beliefs and culture

$1148 \quad 1.00(0-3.00) \quad 1201 \quad 1.00(0-3.00)$

42 Feeling pressured to consent or silence in response to frauds for the benefit of the institution $\quad \begin{array}{lll}1152 & 2.00(0-5.00) & 1198 \quad 2.00(0-4.00)\end{array}$

44 Feeling impotent to defend the patient's autonomy

45 Recognizing situations of disrespect/mistreatment by professionals toward the user

46 Recognizing situations of disrespect for users' right to privacy/intimacy

47 Recognizing situations of disrespect for the user's right to confidentiality/secrecy

48 Recognizing situations of disrespect for patients and relatives' right to information

$1148 \quad 3.00(1.00-5.00) \quad 1198 \quad 3.00(1.00-4.00)$

$1148 \quad 2.00(1.00-4.00) \quad 1199 \quad 2.00(1.00-3.00)$

$11412.00(1.00-4.00) \quad 1194 \quad 2.00(1.00-3.25)$

$11472.00(1.00-3.00) \quad 1200 \quad 2.00(1.00-3.00)$

$11472.00(1.00-4.00) \quad 1198 \quad 2.00(1.00-3.00)$

$1145 \quad 2.00(1.00-4.00) \quad 1199 \quad 2.00(1.00-4.00)$

49 Feeling unable to defend the user in situations of social vulnerability

$11563.00(2.00-6.00) \quad 1202 \quad 3.00(2.00-5.00)$

08 Recognizing that the consumption material is insufficient

$11623.00(2.00-5.00) \quad 1206 \quad 3.00(1.00-5.00)$

09 Recognizing that the consumption material is unsuitable

10 Recognizing that the fixed equipment/material available is insufficient

$11583.00(2.00-5.00) \quad 1203 \quad 3.00(2.00-5.00)$

11 Recognizing that the fixed equipment/material available is unsuitable

$11523.00(2.00-5.00) \quad 1206 \quad 3.00(2.00-5.00)$

12 Recognizing that the service facilities are insufficient

$11523.00(2.00-6.00) \quad 1198 \quad 3.00(2.00-5.00)$

13 Recognizing that the service facilities are unsuitable

$1153 \quad 3.00(2.00-6.00) \quad 1201 \quad 3.00(2.00-5.00)$

\section{Factor 5 - Ethical infractions}

17 Experiencing omission by the physician

18 Experiencing imprudence by the physician

$11603.00(2.00-5.75) \quad 1204 \quad 3.00(2.00-5.00)$

19 Experiencing omission by the nurse

$11563.00(1.00-5.00) \quad 1202 \quad 3.00(1.00-4.00)$

$11532.00(1.00-4.00) \quad 1200 \quad 2.00(1.00-3.00)$

20 Experiencing imprudence by the nurse

$11552.00(1.00-4.00) \quad 1205 \quad 2.00(1.00-3.00)$

21 Experiencing omission by professionals in other categories

22 Experiencing recklessness by professionals from other categories

$1154 \quad 2.00(1.00-4.00) \quad 1202 \quad 2.00(1.00-4.00)$

$11492.00(1.00-4.00) \quad 1206 \quad 2.00(1.00-4.00)$

\section{Factor 6 - Work teams}

1Working with an insufficient number of professionals to attend to the demand

2 Working with an incomplete multiprofessional health team

3 Experiencing conditions of work overload

4 Working with unprepared physicians

5 Working with unprepared nurses

6 Working with unprepared auxiliary nurses and nursing technicians

7 Working with unprepared professionals from other categories

$11554.00(2.00-6.00) \quad 1209 \quad 3.00(2.00-6.00)$

$11503.00(2.00-5.00) \quad 1208 \quad 3.00(2.00-5.00)$

$11594.00(3.00-6.00) \quad 1202 \quad 4.00(2.00-6.00)$

$1153 \quad 3.00(2.00-5.00) \quad 1206 \quad 3.00(2.00-5.00)$

$11493.00(1.00-5.00) \quad 1207 \quad 3.00(1.00-4.00)$

$11573.00(1.00-5.00) \quad 1206 \quad 3.00(1.00-4.00)$

$11613.00(2.00-5.00) \quad 1203 \quad 3.00(2.00-4.00)$

*Md (median) **Ilq (interquartile range). 
Table 3 - Descriptive statistics of the frequency and intensity of moral distress according to factors - Brazil, 2018.

\begin{tabular}{|c|c|c|c|c|}
\hline \multirow{2}{*}{ Factor } & \multicolumn{2}{|c|}{ Intensity } & \multicolumn{2}{|c|}{ Frequency } \\
\hline & $\mu( \pm S)$ & $\operatorname{Md}(\mathrm{IIq})$ & $\mu( \pm S)$ & $\operatorname{Md}(\mathrm{Ilq})$ \\
\hline Acknowledgement, power and professional identity & $3.36( \pm 1.59) *$ & $3.18(2.00-4.74)$ & $3.23( \pm 1.56)^{*}$ & $3.00(1.93-4.55)$ \\
\hline Safe and qualified care & $3.31( \pm 1.66)$ & $3.18(2.00-4.81)$ & $3.18( \pm 1.61)$ & $3.00(1.91-4.55)$ \\
\hline Defense of values and rights & $2.47( \pm 1.67)$ & $2.13(1.13-3.50)$ & $2.25( \pm 1.52)$ & $2.00(1.13-3.25)$ \\
\hline Work conditions & $3.33( \pm 1.78)$ & $3.00(2.00-5.00)$ & $3.22( \pm 1.75)$ & $3.00(1.83-4.83)$ \\
\hline Ethical infractions & $2.80( \pm 1.74)$ & $2.50(1.33-4.17)$ & $2.54( \pm 1.55)$ & $2.33(1.33-3.67)$ \\
\hline Overall MD & $3.08( \pm 1.45)^{*}$ & $3.00(1.87-4.27)$ & $2.94( \pm 1.37)^{*}$ & $2.89(1.82-4.05)$ \\
\hline
\end{tabular}

(*) Pearson's coefficient of variation less than $50 \%$.

\section{DISCUSSION}

Data from this study point to a universe of female nurses, as other studies directed to moral distress ${ }^{(11-12,20-21)}$, and in line with a survey promoted by the Federal Council of Nursing, in which it was found that $84.2 \%$ of nursing professionals in the area are female and $15.8 \%$ are male. The age group of 30 to 39 years was also present in other studies of moral distress ${ }^{(2,7,11,22)}$, as well as the average time of training of 10 years $^{(7,11)}$, although they do not indicate a significant correlation between sex, age and time since graduation with MD. Only one study found a significant correlation when women with further training had higher levels of MD than men with the same level of education ${ }^{(22)}$.

The findings indicated moderate levels of MD intensity in four out of the six factors. The factor "Acknowledgement, power and professional identity" was highlighted in the frequencies and intensities of MD situations. It indicated that difficulties in expressing nurses' identity in working relationships are triggers, that is, they are triggering elements or predictors of the occurrence of $\mathrm{MD}$, especially when professionals feel undervalued, discriminated or with their autonomy impeded. Other studies in different contexts of Brazil also revealed that this type of predictor of MD intervenes in job satisfaction, whether for the loss of autonomy and devaluation of nurses' actions by other members of the health team, particularly physicians; or when their ethical actions suffer interference from institutional rules and their autonomy in the care of users is weakened ${ }^{(7-8,11,20,22)}$.

In the factor "Defense of values and rights", the only highlighted item referred to the feeling of powerlessness in the defense of patient autonomy, since the other items of this factor had the lowest values on the scale. In a study conducted in southern Brazil, disrespect for patient autonomy presented the highest intensity of MD in nursing professionals. However, what differentiated them was the measurement instrument used, since the professionals in that study answered an international scale validated and adapted in Brazil, in which the main questions were related to medical procedures, conduct of terminal care and post-resuscitation after cardiac arrest ${ }^{(23)}$.

Although nurses have higher values of frequency and intensity of MD in matters related to their technical competence and professional identity, they may be able to develop their actions in favor of users' rights and principles, such as comprehensive care and access to care, since the factor related to the Defense of values and rights obtained the lowest values of MD. Still, it is not possible to rule out the possibility that incomplete perception about the scope of such rights leads to impaired sensitivity to detect possible disrespect.

In favor of the first interpretation (lower MD by greater potential of action or defense), the Brazilian legal framework regarding the universal right to health, the services of the National Health System and the users' Bill of Rights (Ordinance 1.820/09) should be considered, as they have all of users' rights and duties in relation to health services, whether public or private ${ }^{(24)}$. Legal guarantees and changes in professional training may already be altering the perception of problems related to some rights. Both because such rights may be more respected and because a professional intervention may ensure a more effective protection of these rights, i.e., professionals feel less impotent and more protected or with a greater defense ability.

It is possible to reinforce the thesis that the feeling of powerlessness is related to reduced resistance and ethical, political and advocacy insufficiency ${ }^{(14)}$. Advocacy refers to the ability to act in defense and in favor of interests of patients/ users of care/health services. This is consistent with the idea that public policies favorable to users' rights are also instruments for professional empowerment, as they provide a consistent basis to argue for the quality of services and care. According to this finding, the teams' approach to MD increases their coping power ${ }^{(25)}$.

In the factor "Work Teams", the issues with higher intensity and frequency of MD portray the precarious scenario to which workers are exposed, such as issues related to work overload and insufficient staff and time to provide care. Other studies have also highlighted the poor working conditions associated with high MD, showing the contrast between the need to provide adequate assessment and care to patients and their impossibility due to a lack of professionals and the high demand, relating work overload and harm to the safety and care of patients ${ }^{(7,11)}$.

From this angle and by the aforementioned aspects of patient defense and working conditions, item 17 Experiencing omission by the physician - stands out in the factor "Ethical infractions" because of its higher values. In contrast, experiencing situations in which the physician omits or performs actions considered unethical by nursing proved to be an item of low index in a study of the North American scenario ${ }^{(22)}$. This predictor refers to differences related to training and professional skills in different realities, and to the historical constitution of the fields of work and professional practice in each country, where there is influence of aspects of hegemony and institutional practices of greater 
or lesser progress in terms of teamwork, interdisciplinary practices, and quality of environments and working relationships. Particularly in the international context of primary care, physicians and nurses have shown errors of omission in patient follow-up, education, emotional support, and mental health of patients, calling attention to the factors which lead to such omissions, for example, time constraints, inappropriate routines, and administration burdens, and highlight the workloads in the omission equation ${ }^{(26)}$. The omissions described refer to the care that goes beyond more traditional clinical behaviors towards the physical symptom or disease but indicate the way in which education or the outlook on the emotional component is neglected. In situations of overload or lack of time, professionals set priorities or comply with those dictated by the institution, and fail to evaluate, from the ethical prism or from the patient's needs, the best, fairest and most correct action to take. In Brazilian services, at this same level of care, impairments in access and quality of care are also related to high workloads ${ }^{(4)}$. Likewise, conditions of work organization have been decisive about political principles, rights and values of care, without professionals feeling effective to change the limiting conditions.

These findings can be related with important reflections made (including the national context) on patient advocacy as an individual and collective professional responsibility. One of the barriers for the nurse's practice of patient advocacy is imposed when such defense implies questioning or challenging medical decisions ${ }^{(27)}$.

According to items 21 and 22 of the scale, omission and recklessness by physicians reached higher intensity and frequency of MD within the "Ethical infractions" factor. When these same failures were identified in nurses and other professionals, they reached lower values. Hence, the questioning about the origin of this result; if because the number of occurrences of ethical infractions by physicians was higher, or by the fact that nurses feel more powerless or unable to cope, denounce and change the situation precisely because it was perceived in these professionals. In addition, there are shortcomings when evaluating oneself or the other, considering the interference of previous feelings and experiences, sensitivity and moral competencies ${ }^{(15,28)}$. That is, one must be alert about the quality and neutrality of moral judgments that depend on capacities in permanent construction and when one is subject to difficulties of exemption and self-criticism.

Another Brazilian study using an adapted international scale showed that lack of competence in the work team is the most frequent cause of MD, especially regarding medical professionals with higher mean values than those of other professionals ${ }^{(26)}$. The authors relate this result to the nursing team's need of power exercise, and the difficulty in coping with conflicts with other professionals. The "Defense of values and rights" factor can be related to professionals' capacity of assuming a stance and expressing themselves ethically, in close connection with technical competence, given that power is exercised in the field of practice and in the relationship with others, in moral, clinical and managerial decisions, among others.
The factor "Safe and qualified care" in item 32 Recognizing routines and practices that are inappropriate to the relatives/companions'safety - presented lower intensity and frequency of MD. Given the scarcity of studies, it is not possible to establish a direct relationship between MD and safety practices to family members or caregivers, which shows the need for further investigation. However, it is possible to address some triggers, i.e., elements that trigger MD as situations representing threat or harm to patient safety, for example, the recognition of inappropriate behaviors, continuous treatments without adequate therapeutic response, and health actions without the necessary knowledge to develop them ${ }^{(2,26)}$. Apparently, a situation that triggers $\mathrm{DM}$, whether occasional or frequent, can predict MD and indicate the importance of some conditions. In the case of the factor under consideration, safety of care is an assumed value, and practices that do not express such value can be perceived as threats to both the other and the sense of professional accomplishment.

The similarity between the intensity and frequency results, with moderate values prevailing, may be suggestive for future inquiries about the sufficiency of the intensity measure to evaluate the phenomenon, or even that the intensity of the experience may be more representative in case of regular and persistent manifestations. This is an additional observation in relation to the study with the international scale adapted in Brazil that showed differences between intensity and frequency values ${ }^{(29)}$.

Regarding the evaluation of overall MD, Brazilian nurses had moderate levels, similar to studies in specific institutional contexts in the country ${ }^{(26,29)}$. This denotes the need for more depth on MD predictive elements and strategies that minimize the effects of its occurrence, which will equip nurses for acting ethically in relation to conflicting situations and daily challenges and promote healthier and more satisfactory work environments. Challenges and conflicts are not always explicitly linked to the field of moral deliberation, but integrate clinical, managerial, and educational decisions and procedures, or the whatever exists conflicts of values or tensions between diverse, institutional, individual, or group perspectives and interests.

Since this is a descriptive study, it is not possible to make correlations between the factors and variables, and between the factors themselves, which characterized a limitation. From this limitation, one suggests further investigations that may contribute to unveil MD as a procedural phenomenon in the daily lives of professional nurses.

\section{CONCLUSION}

From the descriptive analysis, it became clear that MD was present in the daily routine of nurses at a moderate level of intensity and frequency, in four out of the six factors. In factors "Acknowledgement, power and professional identity" and "Work conditions", all issues had moderate levels. This expresses the occurrence of MD in precarious work environments and with little expressiveness of nurses' role. 
The "Work Teams" factor stood out in intensity and frequency because it was the only one with median MD values above moderate, mainly related to work overload issues.

Another important finding of the study refers to $\mathrm{MD}$ at levels below moderate in most items of the "Defense of values and rights" factor, which led to a reflection on whether nurses were understanding their role as users' advocates and feeling more capable to act in defense of their rights of access and quality of healthcare. In contrast, issues about omission and recklessness by physicians, professionals who should also act on behalf of users, reached higher intensity and frequency of MD within the "Ethical Infractions" factor, albeit at moderate levels.

The identification of factors related to the phenomenon in the Brazilian context evidenced the importance of the problem in terms of its amplitude and multicausality, reaching professionals who work in different work contexts. A broader understanding of the conditions is needed, as well as the appreciation of professional practice in order to support more efficient strategies for achieving ethically and organizationally healthier work environments and relationships.

The impact of the study is evident for understanding the problem. It also represents a subsidy for professional and institutional policies that consider the mutual interference between organizational aspects of work, the quality of healthcare products and the subjective experiences of professionals, thereby articulating complex effects and implying strategies for appreciation of subjects, their autonomy and skills for ethically responsible action.

\section{RESUMO}

Objetivo: Avaliar a frequência e a intensidade de distresse moral em enfermeiros brasileiros. Método: Estudo transversal desenvolvido com enfermeiros dos 27 estados brasileiros por meio da aplicação da Escala Brasileira de Distresse Moral e análise estatística descritiva. Resultados: Participaram do estudo 1.226 enfermeiros brasileiros. A intensidade e a frequência de distresse moral geral foram avaliadas como nível moderado, com médias de 3,08( $\pm 1,45)$ e 2,94( $\pm 1,37)$, respectivamente. Especificamente, a maior intensidade e frequência esteve relacionada aos fatores Reconhecimento, poder e identidade e Equipes de trabalho, enquanto a menor ao fator Defesa de valores e direitos. Conclusão: Denota-se a ocorrência do distresse moral em ambientes precários de trabalho e com pouca expressividade do papel do enfermeiro. Destaca-se a importância do problema em termos de sua amplitude e multicausalidade, atingindo profissionais que atuam em diferentes contextos de trabalho.

\section{DESCRITORES}

Ética em Enfermagem; Condições de Trabalho; Equipe de Assistência ao Paciente; Moral; Esgotamento Profissional.

\section{RESUMEN}

Objetivo: Evaluar la frecuencia y la intensidad de distrés moral en enfermeros brasileños. Método: Estudio transversal desarrollado con enfermeros de los 27 estados brasileños mediante la aplicación de la Escala Brasileña de Distrés Moral y análisis estadístico descriptivo. Resultados: Participaron en el estudio 1.226 enfermeros brasileños. La intensidad y la frecuencia de distrés moral general fueron evaluadas como nivel moderado, con promedios de 3,08( $\pm 1,45)$ y 2,94( $\pm 1,37)$, respectivamente. Específicamente, la mayor intensidad y frecuencia estuvo relacionada con los factores Reconocimiento, poder e identidad y Equipos de trabajo, mientras que la menor con el factor Defensa de valores y derechos. Conclusión: Se denota la ocurrencia del distrés moral en ambientes precarios de trabajo y con poca expresividad del papel del enfermero. Se destaca la importancia del problema en términos de su amplitud y multicausalidad, alcanzando a los profesionales que actúan en distintos contextos laborales.

\section{DESCRIPTORES}

Ética en Enfermería; Condiciones de Trabajo; Grupo de Atención al Paciente; Moral; Agotamiento Profesional.

\section{REFERENCES}

1. Loro MM, Zeitoune RCG. Collective strategy for facing occupational risks of a nursing team. Rev Esc Enferm USP. 2017;51:e03205. DOI: http://dx.doi.org/10.1590/S1980-220X2015027403205

2. Musto LC, Rodney PA, Vanderheide R. Toward interventions to address moral distress: Navigating structure and agency. Nurs Ethics. 2015; 22(1):91-102. DOI: http://dx.doi.org/10.1177/0969733014534879

3. Ramos FRS, Barth PO, Schneider AMM, Cabral AS, Reinaldo JS. Effects of moral distress on nurses: Integrative literature review. Cogitare Enferm. 2016;21(2):1-13.

4. Pires DEP, Machado RR, Soratto J, Scherer MA, Gonçalves ASR, Trindade LL. Nursing workloads in family health: implications for universal access. Rev Latino Am Enfermagem. 2016;24:e2682. DOI: http://dx.doi.org/10.1590/1518-8345.0992.2682

5. Barth PO, Ramos FR, Barlem ELD, Dalmolin GD, Schneider DG. Validation of a moral distress instrument in nurses of primary health care. Rev Latino Am Enfermagem. 2018; 26:e3010. DOI: http://dx.doi.org/10.1590/1518-8345.2227.3010

6. Jameton A. A reflection on moral distress in nursing together with a current application of the concept. J Bioeth Inq. 2013;10(3):297-308. DOI: http://dx.doi.org/ 10.1007/s11673-013-9466-3

7. Dyoa M, Kalowesb P, Devries J. Moral distress and intention to leave: a comparison of adult and paediatric nurses by hospital setting. Intensive Crit Care Nurs. 2016;36:42-8. DOI: http://dx.doi.org/10.1016/j.iccn.2016.04.003

8. Wolf LA, Perhats C, Delao AM, Moon MD, Clark PR, Zavotsky KE. "It's a burden you carry": describing moral distress in emergency nursing. J Emerg Nurs. 2016;42(1):37-46. DOI: http://dx.doi.org/10.1016/j.jen.2015.08.008

9. Mccarthy J, Gastmans C. Moral distress: a review of the argument-based nursing ethics literature. Nurs Ethics. 2015;22(1):131-52. DOI: http://dx.doi.org/ 10.1177/0969733014557139

10. Woods M, Rodgers V, Towers A, Grow SL. Researching moral distress among New Zealand nurses: a national survey. Nurs Ethics. 2015;22(1):117-30. DOI: http://dx.doi.org/10.1177/0969733014542679 
11. Veer AJE, Francke AL, Struijs A, Willems DL. Determinants of moral distress in daily nursing practice: a cross sectional correlational questionnaire survey. Int J Nurs Stud. 2013;50(1):100-8. DOI: http://dx.doi.org/10.1016/j.ijnurstu.2012.08.017

12. Musto L, Rodney $P$, Vanderheide R. Toward interventions in moral distress: navigating reciprocity between structure and agency. Nurs Ethics. 2015;22(1):91-102. DOI: https://doi.org/10.1177/0969733014534879

13. Ramos FRS, Barlem ELD, Brito MJM, Vargas MA, Schneider DG, Brehmer LCDF. Conceptual framework for the study of moral distress in nurses. Texto Contexto Enferm. 2016;25(2):e4460015. DOI: http://dx.doi.org/10.1590/0104-07072016004460015

14. Barlem ELD, Ramos FRS. Constructing a theoretical model of moral distress. Nurs Ethichs. 2014;22(5):608-15. DOI: http://dx.doi.org/ $10.1177 / 0969733014551595$

15. Ramos FRS, Barlem ELD, Brito MJM, Vargas MA, Schneider DG, Brehmer LCDF. Construction of the Brazilian Moral Distress Scale in Nurses: a metodological study. Texto Contexto Enferm. 2016;26(4):e0990017. DOI: http://dx.doi.org/10.1590/0104-07072017000990017

16. Corley MC, Minick P, Elswick RK, Jacobs M. Nurse moral distress and ethical work environment. Nurs Ethics. 2005;12(4):381-90. DOI: http://dx.doi.org/10.1191/0969733005ne809oa

17. Oh Y, Gastmans C. Moral distress experienced by nurses: a quantitative literature review. Nurs Ethics. 2015;22(1):15-31. DOI: http:// dx.doi.org/10.1177/0969733013502803

18. Schaefer R, Zoboli ELCP, Vieira M. Identification of risk factors for moral distress in nurses: basis for the development of a new assessment tool. Nurs Inq. 2016;23(4):346-57. DOI: http://dx.doi.org/10.1111/nin.12156

19. Bolfarine H, Bussab WO. Elementos de amostragem. São Paulo: Blucher; 2005.

20. Shoorideh FA, Ashktorab T, Yaghmaei F, Majd HA. Relationship between ICU nurses' moral distress with burnout and anticipated turnover. Nurs Ethics. 2015;22(1):64-76. DOI: http://dx.doi.org/10.1177/0969733014534874

21. Lusignani M, Gianni ML, Re LG, Buffon ML. Moral distress among nurses in medical, surgical and intensive-care units. J Nurs Manag. 2016. DOI: http://dx.doi.org/10.1111/jonm.12431

22. O'Connell CB. Gender and the experience of moral distress in critical care nurses. Nurs Ethics. 2015;22(1):32-42. DOI: http://dx.doi. org/10.1177/0969733013513216

23. Barlem ELD, Lunardi VL, Lunardi GL, Tomaschewski-Barlem JG, Silveira RS. Moral distress in everyday nursing: hidden traces of power and resistance. Rev Latino Am Enfermagem. 2013;21(1). DOI: http://dx.doi.org/10.1590/S0104-11692013000100002

24. Brasil. Ministério da Saúde. Portaria n. 1.820, de 13 de agosto de 2009. Dispõe sobre os direitos e deveres dos usuários da saúde [Internet]. Brasília; 2009 [citado 2018 mar. 01]. Disponível em: http://bvsms.saude.gov.br/bvs/saudelegis/gm/2009/prt1820_13_08_2009.html

25. Hamric AB, Epstein EG. A health system-wide moral distress consultation service: development and evaluation. HEC Forum. 2017;29(2):27-143.

26. Barlem ELD, Lunardi VL, Lunardi GL, Tomaschewski-Barlem JG, Almeida AS. Psycometric characteristics of the Moral Distress Scale in Brazilian nursing professionals. Texto Contexto Enferm. 2014;23(3):563-72. DOI: http://dx.doi.org/10.1590/0104-07072014000060013

27. Tomaschewski-Barlem JG, Lunardi VL, Barlem ELD, Silveira RS, Ramos AM, Piexak. Patient advocacy in nursing: barriers, facilitators and Potential implications. Texto Contexto Enferm. 2017;26(3):e0100014. DOI: http://dx.doi.org/10.1590/0104-0707201700010001

28. Johnstone MJ, Hutchinson A. 'Moral distress' - time to abandon a flawed nursing construct? Nurs Ethics. 2015;22(1):5-14. DOI: http:// dx.doi.org/ 10.1177/0969733013505312

29. Poghosyan L, Norful AA, Fleck E, Bruzzese JM, Talsma NA, Nannini A. Primary care providers' perspectives on errors of omission. J Am Board Fam Med. 2017;30(6):733-42. DOI: http://dx.doi.org/10.3122/jabfm.2017.06.170161

Conselho Nacional de Desenvolvimento Científico e Tecnológico - CNPq. Process number 471859/2013-3. 